\title{
Comparison of a DNA probe assay with culture for the detection of Chlamydia trachomatis
}

\author{
M. I. LEES, DIANE M. NEWNAN and SUZANNE M. GARLAND
}

Microbiology Department, The Royal Women's Hospital, 132 Grattan Street, Carlton 3053, Victoria, Australia

\begin{abstract}
Summary. A new DNA probe assay (PACE 2, Gen-probe) was compared with cell culture for the detection of Chlamydia trachomatis in 909 women attending the Royal Women's Hospital, Melbourne, Victoria. The DNA probe assay had a sensitivity of $86.2 \%$, a specificity of $99.9 \%$ and a positive predictive value of $96.2 \%$ in a population with $3.2 \%$ prevalence, indicating that it may be a suitable alternative to culture for the detection of $C$. trachomatis in specimens from the genital tract.
\end{abstract}

\section{Introduction}

Chlamydia trachomatis is the most commonly encountered sexually transmitted disease in developed countries; the benchmark method for its diagnosis in the laboratory is cell culture. ${ }^{1}$ Other techniques for laboratory diagnosis, such as enzyme immunoassay (EIA) and direct antigen fluorescence (DF), are available but, although more rapid to perform, they are less sensitive than cell culture. Consequently, in populations where the prevalence of chlamydial carriage is low, the positive predictive value of these more rapid techniques becomes less acceptable. ${ }^{2}$

Recently, a new DNA probe assay (PACE 2; GenProbe, San Diego, CA, USA) that has a non-isotopic label and detects ribosomal RNA of $C$. trachomatis has become available commercially. PACE 2 supercedes a previous assay, PACE 1 , and has the advantages of being simpler to perform and of greater sensitivity. We compared the DNA probe assay with cell culture in a female population with low prevalence of chlamydial infection.

\section{Materials and methods}

The study population was 909 women attending the Royal Women's Hospital, Victoria, Australia between August and December, 1989 inclusive, and who were seen at the Emergency Department as symptomatic patients (539 women) or were asymptomatic patients attending the Pregnancy Advisory Service (PAS) clinic ( 370 women). At the latter clinic patients are screened routinely for chlamydia before requesting legal termination of pregnancy.

\section{Samples for chlamydial diagnosis}

Endocervical swabs were collected from each patient after cervical mucus or pus was wiped away; the order of swabs was randomised. For culture, a cotton-tipped aluminium ENT swab (Medical Wire and Equipment Co., Wilts) was used; it was placed in transport medium, transported on ice to the laboratory and either cultured the same day or stored at $-70^{\circ} \mathrm{C}$ until processed. For DNA probe (gene probe; GP) assay, specimens were collected according to the manufacturer's instructions. A swab was inserted into the endocervical canal and rotated for 10-30 s. The swab was then carefully withdrawn and placed in GP transport medium and transported to the laboratory on the same day. Each specimen was vortex mixed for $10 \mathrm{~s}$, the swab was discarded and the remaining specimen was either stored at $4^{\circ} \mathrm{C}$, generally for up to 4 days ( 7 days was the acceptable maximum) or stored at $-70^{\circ} \mathrm{C}$ until processed.

Cell culture was performed in 48-well cluster trays as previously described ${ }^{3}$ with the addition of cycloheximide $0.5 \mathrm{mg} / \mathrm{L}$ to the cell maintenance medium. The GP assay was performed in batches of 60 tests (including three positive controls and one negative control) according to the manufacturer's instructions. Samples were allowed to come to room temperature and then vortex mixed for $5 \mathrm{~s}$ to ensure homogeneity, after which $100 \mu \mathrm{l}$ was pipetted into an appropriately labelled tube. Probe reagent was prepared by warming probe diluent in a water bath at $60^{\circ} \mathrm{C}$ for 3-4 min and adding $6 \mathrm{ml}$ to lyophilised probe reagent. This was allowed to stand at room temperature for $2 \mathrm{~min}$ and then vortex mixed for $10 \mathrm{~s}$ before adding $100 \mu \mathrm{l}$ to each specimen. After covering the tubes with sealing cards the specimen mixture was incubated in a waterbath at $60^{\circ} \mathrm{C}$ for $1 \mathrm{~h}$. Concurrently, a separation solution was prepared consisting of $70 \mathrm{ml}$ of activator and $3.2 \mathrm{ml}$ of separation reagent (stable for $6 \mathrm{~h}$ ). This 
separation solution $(1 \mathrm{ml})$ was added to each specimen and allowed to react for $10 \mathrm{~min}$ at $60^{\circ} \mathrm{C}$, after which tubes were placed on a magnetic separation rack for 5 $\min$ at room temperature. The supernates were decanted, and $5 \mathrm{ml}$ of a detergent wash was added and held at room temperature for $20 \mathrm{~min}$. This solution was decanted and the test result for each tube read on a luminometer (Leader 1 ; Gen-Probe) which measured the number of relative light units (RLU) emitted by the specimen. The test result was calculated and expressed as the difference between the response of the specimen and the mean response of the three negative reference replicates. When this difference was $\geq 300 \mathrm{RLU}$, the specimen was regarded as positive, i.e., if the mean response of the negative reference was 73 , the positive-negative cut-off value was 373 RLU.

\section{Results}

The results obtained with 909 specimens tested by GP and cell culture are shown in table I; the sensitivity of the GP assay was $86.2 \%$, with a specificity of $99.9 \%$, a positive predictive value of $96.2 \%$ and a negative predictive value of $99.5 \%$. Two of the four specimens which were positive by culture and negative by GP assay gave RLU values very close to the calculated positive-negative cut-off value and, on re-testing, both gave low positive values. The order of collection did not affect the outcome of the result for either test. Specimens that yielded $<10$ inclusions by culture were all positive by GP assay but generally with low RLU values (table II). High inclusion counts by culture tended to correlate with high RLU values by GP assay.

Table I. Comparison of culture and GP for detection of $C$. trachomatis in endocervical swabs

\begin{tabular}{l|rr}
\hline \multirow{2}{*}{$\begin{array}{l}\text { Culture } \\
\text { result }\end{array}$} & \multicolumn{2}{|c}{ DNA probe result } \\
\cline { 2 - 3 } & \multicolumn{1}{|c}{+} & - \\
\hline+ & 25 & 4 \\
- & 1 & 879 \\
\hline
\end{tabular}

Table II. RLU values for specimens with low inclusion counts

\begin{tabular}{ccr}
\hline $\begin{array}{c}\text { Specimen } \\
\text { no. }\end{array}$ & $\begin{array}{c}\text { Inclusion-forming } \\
\text { units/well }\end{array}$ & $\begin{array}{c}\text { RLU } \\
\text { value }\end{array}$ \\
\hline 1 & 10 & 1439 \\
2 & 10 & 13606 \\
3 & 6 & 6806 \\
4 & 4 & 596 \\
5 & 1 & 654 \\
\hline
\end{tabular}

\section{Discussion}

In comparison with culture, the GP assay, PACE 2, was sensitive $(86.2 \%)$ and specific $(99.9 \%)$ and performed better than the previously published results for PACE 1 , in which sensitivity and specificity were $60 \%$ and $80 \%$ and $95 \%$ and $98 \%$, respectively, and for the $I^{125}$-labelled DNA probe (Gen-Probe), $82.8 \%$ and $99.4 \%{ }^{6}$ The primary modification of the PACE 2 format is an additional chemical separation which corresponds with the mechanical separation step in PACE 1 . The probes used in both PACE 1 and PACE 2 are synthetic oligonucleotides directed against specific ribosomal RNA targets. As RNA is more abundant than genomic DNA, these tests should be more sensitive than tests with other DNA probes directed against genomic or chlamydial plasmid DNA. Results of other studies with non-commercial DNAprobe technology for the detection of $C$. trachomatis have not differed greatly in sensitivity and specificity from the earlier commercially available GP assays. ${ }^{7,8}$ Our results indicate that the manufacturer's modifications in the PACE 2 format have increased the sensitivity of the test. We were able to detect specimens that contained $<10$ IFU, whereas with PACE 1 , Peterson $e t ~ a l^{4}$ experienced difficulty in detecting $<1000 \mathrm{IFU} /$ specimen. The single specimen that gave a positive GP signal ( 3471 RLU) but was culture negative was also negative by DF. This may have been a false positive GP result, or may have resulted from sampling variation for each test from that individual patient.

As with EIA, PACE 2 is suited to the batch testing of large numbers of specimens. We found the assay simple and quick to perform (60 tests could be performed in $3 \mathrm{~h}$ with a total "hands on" time of 90 $\mathrm{min}$ ) and in the vast majority of cases gave very clear results, well above or below the cut-off level. Two specimens yielded levels close to the cut-off and on retesting gave positive results. Consequently, we believe that a borderline zone needs defining with a recommendation that, for specimens which fall into this area after repeat testing, a fresh specimen should be obtained and tested by another method.

The GP assay does not require stringent transport and storage conditions. The manufacturers recommend limits of transport and storage temperature between $2^{\circ} \mathrm{C}$ and $25^{\circ} \mathrm{C}$ for up to 7 days, outside which specimens may be stored frozen at $-20^{\circ} \mathrm{C}$ or $-70^{\circ} \mathrm{C}$. These are similar to the conditions required for EIA techniques and are far less demanding than those for tissue culture, for which specimens may be stored and transported at $4^{\circ} \mathrm{C}$ only for up to $24 \mathrm{~h}$, beyond which freezing at $-70^{\circ} \mathrm{C}$ is mandatory. However, GP is more costly in materials than EIA, although it is still considerably cheaper to perform than tissue culture with conventional coverslips and vials when the labour cost is taken into account. In our laboratory, tissue culture is streamlined by the use of multiwell trays which greatly reduce labour costs. ${ }^{3}$ Under these 
circumstances the total cost of GP and tissue culture would be similar.

In reports of comparisons of each of GP, EIA and DF with culture as the reference method, all of the rapid techniques have yielded similar results. ${ }^{9-14}$ Most studies have been performed in patient populations with a higher prevalence of $C$. trachomatis than ours. As the positive predictive value of a given test varies directly with the prevalence of disease in the population studied, it has been suggested that non-culture methods for the detection of $C$. trachomatis are less

\section{References}

1. Ridgway GL. The laboratory diagnosis of chlamydial infection. In : Oriel D, Ridgway G, Schachter J et al. (eds) Chlamydial infections. Cambridge, Cambridge University Press. 1986: 539-549.

2. Lipkin ES, Moncada JV, Shafer M-A, Wilson TE, Schachter J. Comparison of monoclonal antibody staining and culture in diagnosing cervical chlamydial infection. J Clin Microbiol 1986; 23 : 114-117.

3. Lees MI, Newman DM, Garland SM. Simplified culture procedure for large-scale screening for Chlamydia trachomatis infections. J Clin Microbiol 1988; 26: 1428-1430.

4. Peterson EM, Oda R, Alexander R, Greenwood JR, de la Maza LM. Molecular techniques for the detection of Chlamydia trachomatis. J Clin Microbiol 1989; 27 : 2359-2363.

5. Woods GL, Young A, Scott JC, Blair TMH, Johnson AM. Evaluation of a nonisotopic probe for detection of Chlamydia trachomatis in endocervical specimens. $J$ Clin Microbiol 1990; 28: 370-372.

6. LeBar W, Herschman B, Jemal C, Pierzchala J. Comparison of DNA probe, monoclonal antibody enzyme immunoassay, and cell culture for the detection of Chlamydia trachomatis. $J$ Clin Microbiol 1989; 27 : 826-828.

7. Pao CC, Lin S-S, Yang T-E, Soong Y-K, Lee P-S, Lin J-Y. Deoxyribonucleic acid hybridization analysis for the detection of urogenital Chlamydia trachomatis infections in women. Am J Obstet Gynecol 1987; 156: 195-199. suitable than culture in populations of low chlamydial prevalence. ${ }^{2,12}$ As a positive predictive value of $96.2 \%$ was found for PACE 2 when compared with culture in a population with $3.2 \%$ prevalence of $C$. trachomatis, it must be considered a suitable alternative to culture for the detection of $C$. trachomatis in genital specimens, especially when transport of specimens is difficult.

We sincerely thank the medical and nursing staff of the Emergency Department and the Pregnancy Advisory Clinic, the Royal Women's Hospital for their participation and zeal in this study. The secretarial assistance of $\mathrm{J}$. Jackson and H. Logie is gratefully acknowledged.

8. Horn JE, Quinn T, Hammer M, Palmer L, Falkow S. Use of nucleic acid probes for the detection of sexually transmitted infectious agents. Diagn Microbiol Infect Dis 1986; 4 Suppl 3: $101 \mathrm{~S}-109 \mathrm{~S}$.

9. Mumtaz G, Mellars BJ, Ridgway GL, Oriel JD. Enzyme immunoassay for the detection of Chlamydia trachomatis antigen in urethral and endocervical swabs. J Clin Pathol $1985 ; 38: 740-742$.

10. Mahoney J, CastricianoS, Sellors J et al. Diagnosis of Chlamydia trachomatis genital infections by cell culture and two enzyme immunoassays detecting different chlamydial antigens. J Clin Microbiol 1989; 27 : 1934-1938.

11. Tilton RC, Judson FN, Barnes RC, Gruninger RP, Ryan RW, Steingrimsson $\mathrm{O}$. Multicenter comparative evaluation of two rapid microscopic methods and culture for detection of Chlamydia trachomatis in patient specimens. $J$ Clin Microbiol 1988; 26: 167-170.

12. Lees M, Newnan D, Garland SM. Detection of Chlamydia trachomatis by direct immunofluorescence and culture in genital specimens of symptomatic and asymptomatic women. Venereology 1990; 3: 28-31.

13. Smith JW, Rogers RE, Katz BP et al. Diagnosis of chlamydial infection in women attending antenatal and gynecologic clinics. J Clin Microbiol 1987; 25: 868-872.

14. Chernesky MA, Mahoney JB, Castriciano S et al . Detection of Chlamydia trachomatis antigens by enzyme immunoassay and immunoflurescence in genital specimens from symptomatic and asymptomatic men and women. $J$ Infect Dis $1986 ; 154$ : 141-148. 